\title{
Aktivitas Antifouling Senyawa Bioaktif Dari Lamun di Perairan Pulau Morotai
}

\section{(Antifouling activity of the bioactive compounds from the seagrass on Morotai Island Waters)}

\author{
Nurafni ${ }^{1}$ dan Rinto Muhammad Nur ${ }^{2} *$ \\ ${ }^{1}$ Prodi Ilmu Kelautan, FPIK-Universitas Pasifik Morotai, Morotai \\ ${ }^{2}$ Prodi THP, FPIK-Universitas Pasifik Morotai, Morotai \\ *e-mail: rintomnur777@gmail.com
}

\begin{abstract}
ABSTRAK
Ekosistem lamun merupakan salah satu ekosistem di laut yang mempunyai peranan penting dalam kehidupan biota laut dan merupakan salah satu ekosistem laut yang paling produktif. Lamun banyak dimanfaatkan sebagai bahan pangan, kosmetik, obat-obatan, antibakteri, dan antibiofouling. Di Pulau Morotai banyak ditemukan jenis-jenis lamun, tetapi belum dimanfaatkan oleh masyarakat. Penelitian ini bertujuan untuk memanfaatkan lamun dari perairan Pulau Morotai sebagai bioantifouling. Penelitian ini dilakukan pada bulan Februari sampai November 2018. Sampel lamun diperoleh dari Perairan Desa Posi-Posi, Juanga, Pandanga, dan Daeo. Ekstrasi lamun dilakukan dengan metode maserasi menggunakan pelarut metanol dan n-heksan. Uji aktivitas antifouling menggunakan bakteri biofilm. Identifikasi senyawa bioaktif dilakukan untuk jenis lamun yang memiliki aktivitas antifouling Hasil ekstraksi menunjukkan bahwa rendemen ekstrak dengan pelarut metanol lebih besar dibandingkan dengan n-heksan. Ekstrak terbanyak diperoleh dari ekstrak metanol Cymodecea rotundata (19,32\%), diikuti ekstrak metanol Enhalus acoroides (9,55\%), ekstrak metanol Halodule pinifolia (5,96\%), ekstrak n-heksan Halodule pinifolia (0,53\%), ekstrak n-heksan Enhalus acoroides (0,35\%), dan ekstrak n-heksan Cymodecea rotundata $(0,24 \%)$. Hasil uji antifouling menunjukkan bahwa ekstrak metanol Enhalus acoroides memiliki aktivitas antifouling terhadap bakteri uji. Hasil identifikasai senyawa bioaktif menunjukkan ekstrak metanol Enhalus acoroides mengandung alkaloid, flavonoid, saponin, dan steroid.
\end{abstract}

Kata kunci: lamun, senyawabioaktif, identifikasi, perairanpulaumorotai, ekstraksi

\begin{abstract}
Seagrass ecosystems are one of the ecosystems in the sea that have an important role in the life of marine biota andare one of the most productive marine ecosystems. Seagrass is widely used as food, cosmetics, medicines, antibacterial, and antibiofouling. On Morotai island there are many types of seagrass, but have not been used by the community. This research aimed to utilize seagrass from Morotai Island as bioantifouling. This research was conducted from February to November 2018. Seagrass samples were obtained from the waters of the Posi-Posi, Juanga, Pandanga and Daeo villages. Seagrass extraction was done by maceration method using methanol and n-hexane solvents. Antifouling activity test using biofilm bacteria. Identification of bioactive compounds is carried out on seagrass species that have antifouling activity. The results of extraction indicate that the methanol extraction produce more yield than those of n-hexan. Most extracts were obtained from methanol extract of Cymodecea rotundata (19.32\%), followed by methanol extract of Enhalus acoroides (9.55\%), methanol extract of Halodule pinifolia (5.96\%), n-hexan extract of Halodule pinifolia $(0.53 \%)$, n-heksan extract of Enhalus acoroides $(0.35 \%)$, and n-hexane extract of Cymodecea rotundata $(0.24 \%)$. The antifouling test results showed that the methanol extract of Enhalus acoroides had antifouling activity against the test bacteria. The bioactive compounds in those extract were alkaloids, flavonoids, saponins, and steroids.
\end{abstract}

Keywords: seagrass, bioactive compounds, bioantifouling, morotai island waters, extraction 


\section{Pendahuluan}

Ekosistem lamun merupakan salah satu ekosistem yang mempunyai peranan penting dalam kehidupan biota laut serta merupakan salah satu ekosistem bahari yang paling produktif (Hartati et al., 2012). Peranan penting ekosistem ini adalah sebagai produsen primer, stabilisator dasar perairan, pendaur zat hara, sumber makanan, tempat asuhan dan tempat tinggal. Di Indonesia terdapat 13 spesies lamun dan yang sering ditemukan adalah jenis Enhalus acoroides dan Thalassia hemprichii. Eksplorasi potensi lamun sudah dilakukan dalam beberapa tahun terakhir seperti ekplorasi bioaktif yang terkandung di dalamnya. Dewi (2013) melaporkan bahwa Thalassia hemprichii dan Enhalus acoroides mampu menghambat terjadinya biofilm dengan kategori lemah hingga sedang. Ali et al. (2012) menemukan potensi lamun Cymodocea rotundata yang dapat menghambat pertumbuhan Aegypti larvae. Selain itu, Ravikumar et al. (2008) melaporkan bahwa kandungan senyawa bioaktif lamun yang berasal dari Perairan Selatan India memiliki kemampuan sebagai antibakteri.

Lamun banyak ditemukan di Perairan Pulau Morotai. Sebagaimana yang dilaporkan oleh Purwandani et al. (2014) bahwa ditemukan delapan jenis lamun di Pulau Morotai yaitu Cymodocea rotundata, Cymodocea serrulata, Syringodium isoetifolium, Halodule uninervis, Halodule pinifolia, Enhalus acoroides, Halodule ovalis, dan Thalassia hemprichii. Nurafni dan Nur (2018) juga melaporkan bahwa terdapat 6 jenis lamun di Perairan Dodola, Kabupaten Pulau Morotai yaitu E. acoroides, T. hemprichii, C. rotundata, Halodule pinifolia, Halodule uninervis, dan Halodule ovalis. Banyaknya jenis lamun yang ditemukan di Pulau Morotai tidak sejalan dengan pemanfaatannya, bahkan belum ada pemanfaatan lamun secara ekonomis oleh masyarakat setempat. Oleh karena itu, penelitian ini dilakukan untuk memanfaatkan lamun di Perairan Pulau Morotai sebagai bioantifouling.

\section{Metode Penelitian}

\subsection{Waktu dan tempat penelitian}

Penelitian ini berlangsung dari bulan April sampai November 2018. Sampel lamun diambil dari Perairan Pulau Morotai. Ekstraksi dan identifikasi golongan senyawa dilakukan di Laboratorium Dasar Fakultas Perikanan dan Ilmu Kelautan Universitas Pasifik Morotai, serta pengujian aktivitas antifouling dilakukan di Laboratorium Mikrobiologi Universitas Papua.

\subsection{Prosedur Penelitian}

\subsubsection{Ekstraksi lamun}

Lamun yang diperoleh kemudian dicuci bersih dengan air tawar dan dikeringkan di bawah sinar matahari (ditutupi kain hitam). Lamun yang telah kering selanjutnya dihaluskan dengan blender untuk membentuk simplisia. Ekstraksi lamun dilakukan dengan metode maserasi menggunakan pelarut $\mathrm{n}$-heksan dan metanol secara terpisah. Sampel lamun yang telah dikeringkan (simplisia) dimaserasi dengan perbandingan 1:10 (b/v) selama 48 jam. Selama proses maserasi, sesekali sampel diaduk untuk mempercepat proses penyarian. Setelah 48 jam, filtrat disaring dan diuapkan dengan bantuan kipas angin. Filtrat yang telah kering (berbentuk pasta) selanjutnya dikerok dan disimpan dalam botol flakon.

\subsubsection{Uji aktivitas antifouling}

Uji aktivitas antifouling ekstrak lamun dilakukan dengan menggunnakan bakteri biofilm. Uji ini menggunakan metode difusi agar yang diadopsi dari El-Hadi et al. (2007) dan Jensen et al (1998). 


\subsubsection{Identifikasi senyawa bioaktif}

Identifikasi golongan seyawa bioaktif lamun dilakukan secara kualitatif dengan menggunakan pereaksi kimia. Senyawa bioaktif yang diidentifikasi adalah alkaloid, flavonoid, saponin, dan steroid.

\subsection{Analisis data}

Data jenis lamun, hasil ekstraksi dan identifikasi golongan seenyawa bioaktif lamun dianalisis secara deskriptif kualitatif.

\section{Hasil dan Pembahasan}

\subsection{Hasil}

\subsubsection{Ekstraksi lamun}

Ekstraksi lamun dilakukan dengan metode maserasi dengan menggunakan pelarut metanol dan n-heksan. Metode ini dipilih karena tidak melibatkan panas daalam proses ekstraksi, sehingga kemungkinan rusaknya senyawa bioaktif thermolabil dapat dihindari. Ekstrak yang diperoleh berwarna hijau kekuningan hingga hijau gelap, memiliki tekstur seperti pasta dan lengket. Selain itu, pada ekstrak dengan pelarut metanol ditemukan adanya butiran-butiran bening seperti kristal. Hasil ekstraksi lamun (Tabel 1).

Tabel 1. Hasil Ekstraksi Jenis-Jenis Lamun

\begin{tabular}{llcl}
\hline \multicolumn{1}{c}{ Jenis Lamun } & Pelarut & Rendemen (\%) & \multicolumn{1}{c}{ Warna Ekstrak } \\
\hline Halodule pinifolia & n-heksan & 0,48 & Hijau kekuningan \\
& metanol & 5,98 & Hijau gelap \\
Cymodecea rotundata & n-heksan & 0,24 & Hijau kekuningan \\
& metanol & 19,32 & Hijau gelap \\
Enhalus acoroides & n-heksan & 0,35 & Hijau kekuningan \\
& metanol & 9,55 & Hijau gelap \\
\hline
\end{tabular}

\subsubsection{Uji aktivitas antifouling}

Uji aktivitas antifouling dilakukan dengan menggunakan bakteri biofilm (Staphylococcus auerus). Hasil pengujian menunjukkan bahwa ekstrak Enhalus acoroides memiliki aktivitas antifouling (Tabel 2).

Tabel 2. Hasil Uji Bioantifouling

\begin{tabular}{lc}
\hline \multicolumn{1}{c}{ Jenis Lamun } & Aktifitas hambat bakteri \\
\hline Halodule pinifolia & - \\
Cymodecea rotundata & - \\
Enhalus acoroides & + \\
\hline \multicolumn{2}{c}{ Keterangan: (-): Tidak memiliki aktivitas hambat pada bakteri; (+): Memiliki aktivitas hambat pada bakteri. }
\end{tabular}

\subsubsection{Identifikasi Senyawa Bioaktif Lamun}

Identifikasi golongan senyawa bioaktif lamun terhadap Enhalus acoroides dan dilakuan secara kualitatif dengan menambahkan pereaksi kimia pada ekstrak. Golongan senyawa tertentu jika ditambahkan pereaksi yang sesuai akan menghasilkan warna spesifik, sehingga dapat diidentifikasi golongan senyawa tersebut. Hasil identifikasi golongan senyawa bioaktif ketiga jenis lamun (Tabel 2). 
Tabel 2. Hasil identifikasi senyawa bioaktif Enhalus acoroides

\begin{tabular}{ccc}
\hline \multirow{2}{*}{ Golongan senyawa bioaktif } & \multicolumn{2}{c}{ Pelarut } \\
\cline { 2 - 3 } & n-heksan & metanol \\
\hline alkaloid & - & + \\
flavonoid & + & + \\
saponin & - & + \\
Steroid & + & + \\
\hline
\end{tabular}

Keterangan: (+) mengandung senyawa bioaktif tersebut; (-) tidak mengandung senyawa bioaktif tersebbut.

\subsection{Pembahasan}

Lamun merupakan tumbuhan yang seluruh hidupnya berada di air dan beradaptasi dengan salinitas tinggi. Lamun berpotensi sebagai bahan obat-obatan, kosmetik, antibakteri, dan antifouling. Pemanfaatan lamun ini melalui ekstraksi dengan menggunakan pelarut organik.

Hasil koleksi lamun diperoleh 3 jenis lamun yaitu Halodule pinifolia, Cymodecea rotundata dan Enhalus acoroides. Ketiga jenis lamun ini kemudian diekstraksi dengan n-heksan dan metanol secara terpisah. Hasil ekstraksi menunjukkan bahwa ekstraksi dengan pelarut metanol menghasilkan rendemen yang lebih banyak dibandingkan n-heksan (Gambar 1). Hal ini menunjukkan bahwa ketiga jenis lamun tersebut lebih banyak mengandung senyawa bioaktif yang larut dalam pelarut polar. Kumoro (2015) menjelaskan bahwa metanol mampu menyari senyawa bioaaktif lebih banyak dibadingkan n-heksan. Lebih lanjut Nur and Nugroho (2018) melaporkan bahwa ekstraksi dengan pelarut metanol menghasilkan rendemen lebih banyak.

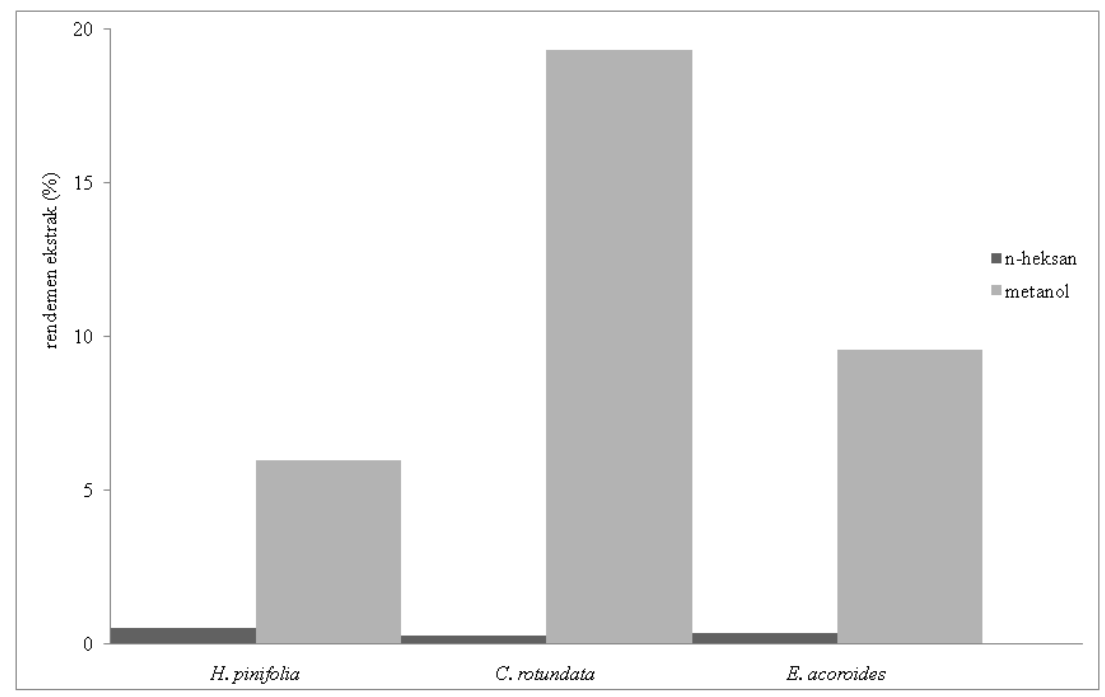

Gambar 1. Perolehan rendemen ekstrak n-heksan dan metanol lamun.

Hasil ekstraksi dengan metanol menunjukkan rendemen terbanyak terdapat pada jenis Cymodecea rotundata (19,32\%), diikuti Enhalus acoroides (9,55) dan Halodule pinifolia $(5,98 \%)$. Sementara itu, perolehan rendemen ekstrak dengan pelarut n-heksan terbanyak yaitu jenis Halodule pinifolia $(0,48 \%)$ diikuti Enhalus acoroides $(0,35 \%)$ dan Cymodecea rotundata $(0,24 \%)$. Keberadaan senyawa bioaktif dalam suatu tumbuhan berbeda-beda tergantung jenis dan lingkungan tempat tinggalnya. Wink (2010) menjelaskan bahwa senyawa bioaktif tidak berperan secara langsung terhadap pertumbuhan dan perkembangan tumbuhan, tetapi berperan dalam 
kompetisi terhadap tanaman lain. Selain itu, senyawa bioaktif juga dihasilkan sebagai pertahanan terhadaap stres lingkungan (Dewick, 2002).

Ekstrak yang diperoleh selanjutnya dilakukan uji aktivitas antifouling-nya. Hasil uji antifouling menunjukkn ekstrak metanol Enhalus acoroides memiliki aktivitas antifouling, sedangkan ekstrak Cymodecea rotundata dan Halodule pinifolia tidak menunjukkan aktivitas antifouling. Dewi (2013) melaporkan bahwa ekstrak daun Enhalus acoroides mampu menghambat terjadinya biofilm dengan kategori lemah hingga sedang. Menurut Schwarz et al. (1999) ketidakmampuan suatu ekstrak untuk menghambat beberapa strain bakteri uji menunjukan adanya kemampuan mekanisme resistensi inaktivasi enzimatik, modifkasi tempat target, atau konsentrasi senyawa ada dalam jumlah yang tidak cukup untuk menghasilkan penghambatan.

Hasil identifikasi senyawa bioaktif menunjukkan bahwa Enhalus acoroides mengandung golongan senyawa bioaktif alkaloid, flavonoid, saponin, dan steroid. Dewi et al. (2012) melaporkan bahwa Enhalus acoroides mengandung senyawa alkaloid, flavonoid dan steroid. Qi et al. (2008) juga melaporkan bahwa senyawa bioaktif utama yang terdapat dalam Enhalus acoroides adalah senyawa flavonoid dan steroid. Enhalus aacoroides da Cymodecea rotundata mengandung senyawa flavonoid, tanin dan steroid (Putri, 2013). Rumianti (2001) melaporkan bahwa Enhalus acoroides mengandung senyawa fenol hidrokuinon, tanin dan saponin. Gustavina et al. (2018) melaporkan bahwa Enhalus acoroides mengandung senyawa flavonoid, saponin, steroid, dan tanin.

\section{Kesimpulan}

Hasil penelitian dapat disimpulkan bahwa penggunaan metanol sebagai pelarut dapat menyari senyawa bioaktif lamun lebih banyak dibandingkan dengan n-heksan. Ekstrak metanol Enhalus acoroides memiliki aktivitas antifouling dan senyawa bioaktif yang terkandung dalam ekstrak tersebut alkaloid, flavonoid, saponin, dan steroid.

\section{Ucapan Terima Kasih}

Terima kasih kepada Direktorat Riset dan Pengabdian Masyarakat (DRPM) Kementerian Riset, Teknologi dan Pendidikan Tinggi yang telah mendanai penelitian ini melalui Hibah Penelitian Dosen Pemula (PDP) Tahun 2018.

\section{Daftar Pustaka}

Ali MS, Ravikumar S, and Beula. JM, 2012. Bioactivity of seagrass against the dengue fever mosquito Aedes aegypti larvae. Asian Pacific Journal of Tropical Biomedicine (2012)1-5.

Dewi. 2013. Potentian bioactive of Enhalus acoroides and Thalassia hemprichii for Bioantifouling in Pramuka Island, DKI Jakarta. Tesis. Bogor Agricultural University.

Dewi C.S.U., Soedharma D. dan Kawaroe M. 2012. Komponen Fitokimia dan Toksisitas Senyawa Bioaktif dari Lamun Enhalus acoroides dan Thalassia hemprichii dari Pulau Pramuka, DKI Jakarta. Jurnal Teknologi Perikanan dan Kelautan, 3(2): 23-27.

Dewick P.M. 2002. Medicine Natural Products: A Biosynthetic Approach.Second Edition.Wiley. England.

Gustavina N.L.G.W.B., Dharma I.G.B. dan Faiqoh E. 2018. Identifikasi Kandungan Senyawa Fitokimia pada Daun dan Akar Lamun di Pantai Samuh Bali. Journal of Marine and Aquatic Sciences, 4(2): 271-277.

Hartati R, Junaedi A, Hariyadi H, dan Mujiyanto M. 2012. Struktur Komunitas Padang Lamun di Perairan Pulau Kumbang, Kepulauan Karimunjawa (Seagrass Community Structure of Kumbang Waters-Karimunjawa Islands). Ilmu Kelautan: Indonesian Journal of Marine Sciences. 17(4), 217-225. 
Kumoro, A.C. 2015. Teknologi Ekstraksi Senyawa Bahan Aktif dari Tanaman Obat. Plantaxia. Semarang.

Nurafni dan Nur R.M. 2018. Struktur Komunitas Lamun di Perairan Pulau Dodola Kabupaten Pulau Morotai. Prosiding Seminar Nasional KSP2K II, 1(2): 138-145.

Nur RM and Nugroho LH. 2018. Cytotoxic Activities of Fractions from Dioscorea bulbifera L. Chloroform and Methanol Extracts on T47D Breast Cancer Cells. Pharmacognosy Journal, 10(1): 33-38.

Purwandani J.A., Irawan B. dan Pribadi T.D.K. 2014. Struktur Komunitas Lamun di Pulau Morotai Maluku Utara. Biotika, 12(2): 84-91.

Putri A.U. 2013. Uji Potensi Antifungi Ekstrak Brbagai Jenis Lamun terhadap Fungi Candida albicans. [Skripsi] Jurusan Ilmu Kelautan Fakultas Kelautan dan Perikanan Universitas Hasanudin. Makassar.

Qi S.H., Zhang S., dan Qian P.Y. 2008. Antifeedant, Antibacterial and Antilarval Compounds From The South China Seagrass Enhalus acoroides. Botanica Marina 51. Berlin. New York.

Ravikumar, S., Thajuddin, N, P. Suganthi, S. Jacob Inbaneson and Vinodkumar. 2008. Bioactive potential of seagrass bacteria against human bacterial pathogens. Journal of Environmental Biology. 31: 387-389.

Rumianti R.O. 2010. Kandungan Fenol, Komponen Fitokimia dan Aktivitas Antioksidan Lamun Enhalus acoroides [Skripsi]. Fakultas Perikanan dan Ilmu Kelautan, Institut Pertanian Bogor. Bogor.

Wink, M. 2010. Functions and Biotechnology of Plant Secondary Metabolites. Second edition. Annual Plant Reviews Volume 39. Wiley-blakwell. Germany. 